\title{
Farm gate nitrogen surpluses and nitrogen use efficiency of specialized dairy farms in Flanders: Evolution and future goals
}

\author{
F. Nevens ${ }^{a, b, c, *}$, I. Verbruggen ${ }^{a}$, D. Reheul ${ }^{b}$, G. Hofman ${ }^{d}$ \\ ${ }^{a}$ Flemish Policy Research Centre for Sustainable Agriculture, Potaardestraat 20, 9090 Gontrode, Belgium \\ ${ }^{\mathrm{b}}$ Ghent University, Department of Plant Production, Coupure Links 653, 9000 Gent, Belgium \\ ${ }^{\mathrm{c}}$ Catholic University of Leuven, Centre for Agricultural and Environmental Economics, \\ $W$. de Croylaan, 3001 Heverlee, Belgium \\ ${ }^{\mathrm{d}}$ Ghent University, Department of Soil Management and Soil Care, Coupure Links 653, 9000 Gent, Belgium
}

Received 24 August 2004; received in revised form 4 March 2005; accepted 10 March 2005

\begin{abstract}
Data from the Farm Accountancy Data Network revealed that from 1989 to 2001 the average farm-gate $\mathrm{N}$ surplus of Flemish specialized dairy farms decreased from 378 to $238 \mathrm{~kg} \mathrm{~N} \mathrm{ha}^{-1}$, the corresponding whole-farm N efficiency increased from $15 \%$ to $22 \%$. Study of European literature on dairy farming, of experimental farms or farm groups and of progressive Flemish farms showed that there is scope for further improvement of the $\mathrm{N}$ use efficiency in Flemish dairy farming. The improvement can mainly be realized by changes in the operational management, resulting in an ever decreasing use of fertilizer $\mathrm{N}$ and concentrate $\mathrm{N}$. Reasonable targets for sustainable dairy farming in Flanders are $150 \mathrm{~kg} \mathrm{~N} \mathrm{ha}^{-1}$ year ${ }^{-1}$ for the farm-gate $\mathrm{N}$ surplus and about $85 \mathrm{~kg}$ milk kg${ }^{-1} \mathrm{~N}$ surplus for eco-efficiency. These targets can be reached at production levels of up to 10,000 à $12,0001 \mathrm{ha}^{-1}$ and at a satisfying income per unit of labour. (C) 2005 Elsevier Ltd. All rights reserved.
\end{abstract}

Keywords: Dairy faming; Farm gate N surplus; Flanders; Nitrogen use efficiency

\footnotetext{
* Corresponding author. Tel.: + 32926490 67; fax: +3292649094.

E-mail address: Frank.nevens@ugent.be (F. Nevens).
} 


\section{Introduction}

Efficient use of resources, particularly of nutrients, is one of the major assets of sustainable agricultural production systems. Inefficient nutrient use not only results in excessive and potentially harmful losses to the environment, it also negatively affects economic performance of production systems (Oenema and Pietrzak, 2002).

For a specific nutrient (e.g., nitrogen, N), a whole-farm balance or farm-gate balance summarizes inputs and outputs from a single farm. It has an integrative character in encompassing the various types of losses simultaneously (Schröder et al., 2004), the calculated $\mathrm{N}$ surplus can be directly related to measured or modeled $\mathrm{N}$ losses (Jarvis and Aarts, 2000). Inherent uncertainties are usually smaller for a farm-gate balance than for a soil surface or a soil system balance (Oenema et al., 2003). Whole-farm nutrient balances are relatively easy to produce and to standardize, required data are mostly readily available and the results are easy to communicate (Öborn et al., 2003). Introducing nutrient balances on farms increases awareness on nutrient flows in the farming system and the information can serve as a guideline for improvements in nutrient management (Ondersteijn, 2002; Goodlass et al., 2003). This is also the case on livestock farms (Hanegraaf and den Boer, 2003; Swensson, 2003). Hence, a farm-gate balance can be considered a useful and reliable indicator to assess the efficiency and the potential environmental impacts of nutrient use, provided that all relevant terms are included (Schröder et al., 2003).

In addition to completeness, there are other major preconditions for safe and reliable use of farm-gate nutrient balances as a sustainability indicator:

- careful use: comparisons between farms based on balances or surpluses are only justified if major decisive characteristics such as the type of farm (arable versus livestock) and the production intensity (e.g., milk production per ha) are comparable (Schröder et al., 2003);

- availability of reference values (Öborn et al., 2003), this makes it possible to evaluate results and set relevant targets.

In Flanders, as in other European regions, $\mathrm{N}$ losses and $\mathrm{N}$ use efficiency are major concerns in agricultural practice and of policy makers. The high stocking rates in the Flemish region result in a very high $\mathrm{N}$ pressure on the utilized agricultural area, particularly in comparison to other European regions (Pfimlin et al., 2004). Flemish dairy farms use about one third of the available agricultural area (Verbruggen et al., 2004), thus making a major contribution to $\mathrm{N}$ losses from agriculture.

The aim of our research was to calculate the farm-gate $\mathrm{N}$ balances and the corresponding $\mathrm{N}$-use efficiencies of a representative set of specialized dairy farms in Flanders. We studied the observed changes from 1989 to 2001 and compared the average as well as the progressive Flemish dairy farms in a context of European data on $\mathrm{N}$ use in dairy farming. Finally, we made an attempt to establish reference values for necessary, for feasible and for optimal farm-gate $\mathrm{N}$ surpluses on sustainable dairy farms in Flanders. 


\section{Materials and methods}

\subsection{Flemish dairy farms: $N$ surplus and $N$ use efficiency}

The Flemish Farm Accountancy Data Network (FADN) is a database of technical and economic data from a representative set of Flemish farms. We extracted the entries of the specialized dairy farms (i.e., farms on which at least $95 \%$ of the income originates from dairy activity; $n=120$ ) from 1989 to 2001. A selection of average characteristics of the selected dairy farms set is presented in Table 1.

Fig. 1 presents the $\mathrm{N}$ inputs and outputs that were considered in the whole-farm $\mathrm{N}$ balance (on an annual basis). Total $\mathrm{N}$ input is the sum of $\mathrm{N}$ in purchased concentrates, forages and byproducts, straw (or sawdust), animals, mineral fertilizer and manure, in biological fixation and in atmospheric deposition. Total $\mathrm{N}$ output is the total amount of $\mathrm{N}$ in exported milk, animals, manure and crops. All inputs and all outputs are expressed in $\mathrm{kg} \mathrm{N} \mathrm{ha}^{-1}$ of the total utilized farm area. The farm-gate $\mathrm{N}$ surplus was calculated as total $\mathrm{N}$ input-total $\mathrm{N}$ output. The farm $\mathrm{N}$ use efficiency $(\mathrm{in} \%)$ was defined as $100 \times \mathrm{N}$ output $/ \mathrm{N}$ input.

In the available FADN data often $\mathrm{N}$ contents of balance items were not available. In those cases, we calculated $\mathrm{N}$ inputs and $\mathrm{N}$ outputs on the basis of $\mathrm{N}$ contents derived from data of Flemish dairy farm monitoring programmes (Michiels et al., 1998; Verbruggen, 2001) (Table 2). $\mathrm{N}$ input as atmospheric deposition was obtained from the results of the monitoring network of the Flemish Environment Agency (Van Gijseghem and Overloop, 2002). For each year, a single value was used for all farms considered; average total $\mathrm{N}$ deposition for the 1989-2001 period was 48 $\mathrm{kg} \mathrm{ha}^{-1}$ year $^{-1}$. N fixation by leguminous crops was set to $250 \mathrm{~kg} \mathrm{ha}^{-1}$ year $^{-1}$ for lucerne (Van der Hoek, 1990; Whitehead, 1995) and $60 \mathrm{~kg} \mathrm{ha}^{-1}$ year ${ }^{-1}$ for a grass/clover mixture (Van der Hoek, 1990; Kristensen et al., 1995). We considered grasslands

Table 1

A selection of average characteristics of specialized dairy farms in the dataset extracted from the Flemish Farm Accountancy Data Network (1989-2001) $(n=120)$

\begin{tabular}{|c|c|c|c|c|c|c|c|c|}
\hline Characteristic & & 1989 & 1991 & 1993 & 1995 & 1997 & 1999 & 2001 \\
\hline Utilized area & ha & 27.6 & 27.7 & 27.7 & 29.5 & 32.3 & 31.8 & 32.4 \\
\hline $\begin{array}{l}\text { Share of grassland } \\
\text { Annual values }\end{array}$ & $\%$ & 70 & 68 & 65 & 63 & 60 & 62 & 63 \\
\hline Concentrate use & $\mathrm{kg} \mathrm{cow}^{-1}$ & 1236 & 1180 & 1171 & 1291 & 1201 & 1114 & 1132 \\
\hline Mineral fertilization & $\mathrm{kg} \mathrm{N} \mathrm{ha}^{-1}$ & & & & & & & \\
\hline On grassland & & 309 & 277 & 266 & 246 & 273 & 241 & 186 \\
\hline On arable land & & 98 & 82 & 71 & 62 & 56 & 53 & 40 \\
\hline Milk production & Litre & & & & & & & \\
\hline Per cow & & 5319 & 5458 & 5621 & 5709 & 6182 & 5947 & 5827 \\
\hline Per ha & & 9607 & 9625 & 10060 & 10071 & 10328 & 10014 & 9643 \\
\hline Stocking density ${ }^{\mathrm{a}}$ & $\mathrm{LU} \mathrm{ha}^{-1 \mathrm{~b}}$ & 3.02 & 3.10 & 3.10 & 3.18 & 3.06 & 2.99 & 2.98 \\
\hline
\end{tabular}




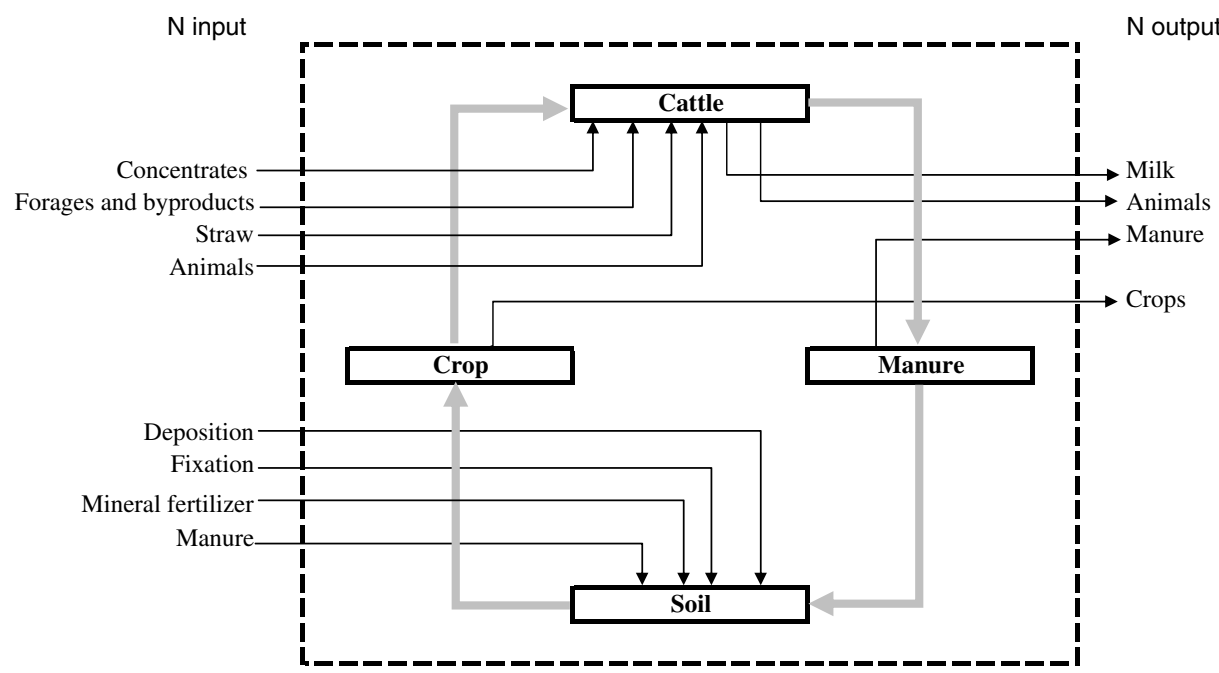

Fig. 1. Farm-gate $\mathrm{N}$ balance: considered inputs and outputs of nitrogen.

Table 2

$\mathrm{N}$ contents for crops, purchased feed and straw $\left(\mathrm{g} \mathrm{kg}^{-1}\right.$ of fresh matter), used in the calculation of the farm balances (sources: Verbruggen et al., 1996; CVB, 2002)

\begin{tabular}{lrlr}
\hline Crops & & Purchased feed & \\
\hline Wheat & 17.8 & Milk powder & 31.3 \\
Barley & 17.1 & Silage maize & 4.0 \\
Spelt & 17.4 & Maize grain & 13.6 \\
Rye & 15.8 & Beet pulp & 3.6 \\
Oat & 17.4 & Brewery grain & 11.7 \\
Sugar beet & 1.8 & Concentrates & 34.4 \\
Potato & 3.2 & & 5.9 \\
& & Straw & \\
\hline
\end{tabular}

to be grass/clover mixtures when applied mineral $\mathrm{N}$ fertilization was less than 100 $\mathrm{kg} \mathrm{N} \mathrm{ha}^{-1}$ year $^{-1}$. Following Anonymous (2000) and Van der Hoek (1990), N in purchased or sold animals was calculated as liveweight $(\mathrm{kg}) \times 0.0253\left(\mathrm{~kg} \mathrm{~N} \mathrm{~kg}^{-1}\right.$ weight). The weight of a milking cow, a heifer and a calve was set to 650,425 and $45 \mathrm{~kg}$, respectively.

Individual farm data on $\mathrm{N}$ input in manure (import of manure is not uncommon on Flemish dairy farms) were only available from 1998 onwards. Since there was no clear trend during the previous decade, we applied the average manure input during 1998-2001 to each of the farms for the earlier years: $25 \mathrm{~kg} \mathrm{~N}^{-1}$ year $^{-1}$.

Stock changes (e.g., conserved forages, straw, etc.) were taken into account: a stock increase of $10 \mathrm{~kg} \mathrm{~N} \mathrm{ha}^{-1}$ year $^{-1}$ was considered as an output of 10 $\mathrm{kg} \mathrm{N}^{-1}$ year $^{-1}$; similarly, a stock decrease was considered as a $\mathrm{N}$ input to the farm. 


\subsection{The Flemish dairy farms in a European context}

We collected and compiled the following recent European literature data on whole-farm $\mathrm{N}$ balances in dairy practice: Verbruggen et al. (1996), Mounsey et al. (1998), Jarvis (1999), Le Gall (2000), Mulier et al. (2001), Soler-Rovira et al. (2001), Verbruggen (2001), Ondersteijn et al. (2002), Sheringer (2002), Swensson (2002), Vertès et al. (2002), Grignani et al. (2003), Hanegraaf and den Boer (2003), Humphreys et al. (2003), Kristensen et al. (2003), Le Gall (2003), Pietrzak and Oenema (2003) and Taube et al. (2003). Atmospheric deposition was a N balance term that was sometimes missing in the surplus calculations in literature. In such cases, we corrected the published results by taking into account a representative average $\mathrm{N}$ deposition for the considered country or region, derived from De Clercq et al. (2001). Based on these literature data, a linear relationship between $\mathrm{N}$ surpluses and dairy production intensity (expressed as $1 \mathrm{milk} \mathrm{ha}^{-1}$ ) was established. Additional to the farm results, we considered data of five experimental dairy farming systems or farm project groups from the Netherlands, all focused on improved $\mathrm{N}$ management in dairy farming: 'De Marke' (Anonymus, 2003), 'AP-Minderhoudhoeve' (Overvest, 2002), 'Koeien en Kansen' (Oenema, 2003; De Vries, 2003), 'Bioveem' (Snijders and Everts, 2000) and 'Vel \& Vanla' (Van der Hem, 2003).

In this European context, we compared the observed changes and the current situation of $\mathrm{N}$ surpluses of the Flemish set of dairy farms.

\subsection{Progressive Flemish dairy farms}

From the Flemish dataset and considering the years 2000 and 2001, we extracted 18 dairy farms ( $\pm 10 \%$ of the total set) that showed the lowest $\mathrm{N}$ surplus in relation to their production intensity. We compared the characteristics of this progressive group with the average of the whole set of dairy farms to identify the characteristics underlying the remarkably good $\mathrm{N}$ use performances.

\subsection{Establishing reference values}

We established reference values for farm-gate $\mathrm{N}$ balances for dairy farms in Flanders, at three levels:

- necessary: what is the maximum permitted farm-gate $\mathrm{N}$ surplus in order to comply with environmental rules or guidelines (e.g., European Nitrates Directive; EU, 1991);

- feasible: what level of farm-gate $\mathrm{N}$ surplus can reasonably be reached, (i.e. technically and without unacceptable economic consequences);

- optimal: which farms perform at the highest level of eco-efficiency? The general business concept of 'eco-efficiency' is defined as "the delivery of competitivelypriced goods and services that satisfy human needs, while progressively reducing environmental impacts and resource intensity throughout the life cycle, to a level at least in line with the earth's estimated carrying capacity" (DeSimone and 
Popoff, 1997). Thus, eco-efficiency links production with ecological effects on the principle to "produce more with less" (Seiler-Hausmann et al., 2004). Lantinga and Groot (1996) illustrated the concept for grassland production by combining total herbage yields and the amount of residual inorganic soil $\mathrm{N}$ at the end of the growing season. In our study, we applied the ratio of milk production to $\mathrm{N}$ balance surplus as a measure of eco-efficiency of a dairy farm.

\section{Results and discussion}

\subsection{Flemish dairy farms: $N$ surplus and $N$ use efficiency}

According to the checklist of necessary values for a complete farm-gate $\mathrm{N}$ balance (Schröder et al., 2003), missing components in our balance calculation method are net mineralization (=mineralization - immobilization), sedimentation and erosion. If we assume that mineralized soil $\mathrm{N}$ is replaced by immobilized $\mathrm{N}$ from newly added organic material (mainly through input of manure) we can omit net mineralization. We have two arguments that justify this assumption. First, the FADN data show no manure output from the farms, even a moderate net input (Table 3). Secondly, studies on the evolution of soils in Flanders show that although there is a general trend of decreasing soil organic matter contents, regions with high livestock activity still show relatively high soil organic matter contents (Sleutel et al., 2003). N output in erosion

Table 3

Flemish dairy farms in 1989 and 2001: components of the $\mathrm{N}$ balance $\left(\mathrm{kg} \mathrm{N} \mathrm{ha}^{-1} \mathrm{year}^{-1}\right.$ ) (standard deviation in brackets)

\begin{tabular}{|c|c|c|c|c|}
\hline & \multirow[t]{2}{*}{1989} & \multirow[t]{2}{*}{2001} & \multicolumn{2}{|c|}{2001 compared to 1989} \\
\hline & & & Absolute & Relative $(\%)$ \\
\hline \multicolumn{5}{|l|}{$N$ input } \\
\hline Mineral fertilizer & $238(82)$ & $128(57)$ & -110 & 53.8 \\
\hline Concentrates & $104(50)$ & $76(36)$ & -28 & 73.1 \\
\hline Manure & $25^{\mathrm{a}}$ & $29(43)$ & +4 & 116.0 \\
\hline Straw & $1(3)$ & $1(3)$ & 0 & 100.0 \\
\hline Forages, byproducts & $26(35)$ & $17(32)$ & -8 & 66.7 \\
\hline Deposition & $50^{\mathrm{a}}$ & $48^{\mathrm{a}}$ & -2 & 96.0 \\
\hline Fixation & $2(9)$ & $6(16)$ & +4 & 300.0 \\
\hline Total & $446(121)$ & $305(90)$ & -141 & 68.4 \\
\hline \multicolumn{5}{|l|}{$N$ output } \\
\hline Milk & 47 (19) & $49(21)$ & +2 & 104.3 \\
\hline Animals ${ }^{\mathrm{b}}$ & $19(8)$ & $16(7)$ & -3 & 84.2 \\
\hline Crops & $2(5)$ & $2(6)$ & 0 & 100.0 \\
\hline Total & $68(24)$ & $67(24)$ & -1 & 98.5 \\
\hline$N$ surplus & $378(111)$ & $238(74)$ & -140 & 63.0 \\
\hline
\end{tabular}

a The same value was used for all the farms.

${ }^{\mathrm{b}}$ Net result of sold animals minus purchased animals. 
and $\mathrm{N}$ input in sedimentation are of minor importance in those regions where Flemish dairy farms are located (Van Rompaey et al., 1999). Hence, we can consider our farm gate $\mathrm{N}$ balance calculations as more or less complete, especially since we included $\mathrm{N}$ deposition and $\mathrm{N}$ fixation, components that are often lacking in other accounting systems (e.g., the Dutch MINAS system).

A second precondition for a sensible use of surpluses on farm gate $\mathrm{N}$ balances (particularly for comparative or trend studies) is that the considered farms have a similar crop export fraction (exported crops/total of produced crops; $100 \%=$ fully arable farming; $0 \%=$ fully livestock farming) and a similar production intensity (1 milk ha ${ }^{-1}$ ) (Schröder et al., 2003). We meet the first condition by our choice to consider only farms on which at least $95 \%$ of the income is generated from dairy activities; the almost unchanged milk production per ha during the period from 1989 to 2001 (Table 1) meets with the condition of comparable intensity of production. Based on these arguments, we can reasonably assume that our calculation method was sound and that comparisons and trends may safely be established.

The average annual $\mathrm{N}$ balance surplus of the FADN dairy farms steadily decreased from $378 \mathrm{~kg} \mathrm{ha}^{-1}$ in 1989 to $238 \mathrm{~kg} \mathrm{ha}^{-1}$ in 2001 (Table 3). The corresponding $\mathrm{N}$ use efficiency increased from $15.1 \%$ to $22.0 \%$. Variation coefficients (=standard deviation:average) of about $30 \%$ indicate considerable differences among farms, but variations of the same magnitude were also found in comparable studies on farm gate $\mathrm{N}$ balances (e.g., Swensson, 2003). It is evident that the observed reduction in $\mathrm{N}$ surplus $\left(-140 \mathrm{~kg} \mathrm{ha}^{-1}\right)$ was solely due to a major reduction of $\mathrm{N}$ input $(-141$ $\mathrm{kg} \mathrm{ha}^{-1}$ or $\left.-32 \%\right)$, primarily of mineral fertilizer $\left(-110 \mathrm{~kg} \mathrm{ha}^{-1}\right)$ and of concentrates $\left(-28 \mathrm{~kg} \mathrm{ha}^{-1}\right)$. $\mathrm{N}$ output ha ${ }^{-1}$ (mainly associated with milk production) hardly changed (Table 3).

\subsection{The Flemish dairy farms in a European context}

Fig. 2 (based on the consulted European literature data) shows a good linear relationship $\left(R^{2}=0.88\right)$ between intensity of dairy farming (in terms of milk production per ha) and average farm-gate $\mathrm{N}$ surplus. Considering this general relation, the average result of the monitored Flemish dataset evolved from a situation of very high surpluses in 1989 to a medium position in 2001 (at a relatively stable production intensity of ca. 10,000 $1 \mathrm{ha}^{-1}$ ). However, there is scope for further improvement. This is illustrated, on the one hand by the results of the Dutch experimental farms or farmer groups and on the other hand by the results of the $10 \%$ best performing (progressive) Flemish dairy farms during 2000 and 2001 (Fig. 2).

\subsection{Progressive Flemish dairy farms}

In 2000 and 2001, the selected group of 18 progressive dairy farms showed an average $\mathrm{N}$ surplus of $163 \mathrm{~kg} \mathrm{ha}^{-1}$ year $^{-1}$, which is $92 \mathrm{~kg} \mathrm{ha}^{-1}$ below the average of the total farm set $\left(255 \mathrm{~kg} \mathrm{~N}^{-1}\right.$ year $\left.^{-1}\right)$; even if the entire sector has moved towards significantly lower $\mathrm{N}$ surpluses, these top performing farms have gone considerably further. The data in Table 4 show that, on average and compared with the 


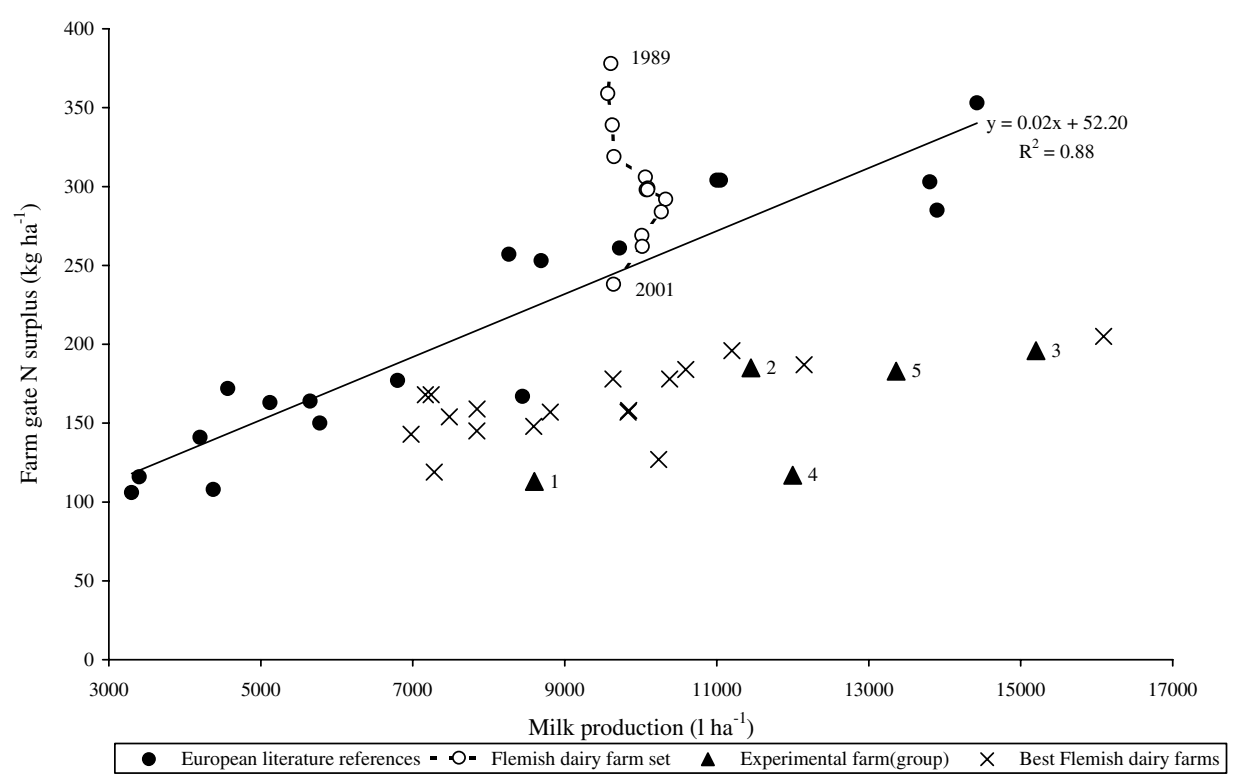

Fig. 2. Farm-gate $\mathrm{N}$ surpluses in relation to production intensity. Data of literature references, average of the Flemish specialized dairy farm set (1989-2001), progressive Flemish dairy farms (2000 and 2001) and Dutch experimental farms (1, Bioveem; 2, Vel and Vanla; 3, Koeien en Kansen; 4, De Marke; 5, AP Minderhoudhoeve).

Table 4

Average characteristics of the specialized dairy farms in the Flemish Farm Accountancy Data Network and of a subgroup of 18 progressive farms with regard to $\mathrm{N}$ use efficiency (data for 2000 and 2001)

\begin{tabular}{|c|c|c|c|c|c|}
\hline \multirow[t]{2}{*}{ Topic } & \multirow[t]{2}{*}{ Unit } & \multirow[t]{2}{*}{$\begin{array}{l}\text { Progressive group } \\
n=18\end{array}$} & \multirow[t]{2}{*}{$\begin{array}{l}\text { All dairy farms } \\
n=148\end{array}$} & \multicolumn{2}{|c|}{$\begin{array}{l}\text { Progressive group } \\
\text { compared to all }\end{array}$} \\
\hline & & & & Absolute & Relative $(\%)$ \\
\hline Utilized area & ha & 34.2 & 32.3 & +1.9 & 106 \\
\hline Stock density & $\mathrm{LU} \mathrm{ha}^{-1}$ & 2.92 & 3.01 & -0.09 & 97 \\
\hline Milk production & $1 \mathrm{ha}^{-1}$ & 9399 & 9831 & -432 & 96 \\
\hline Milk production & $1 \mathrm{cow}^{-1}$ & 5552 & 5925 & -373 & 94 \\
\hline $\mathrm{N}$ surplus & $\mathrm{kg} \mathrm{ha}^{-1}$ & 163 & 250 & -87 & 65 \\
\hline $\mathrm{N}$ use efficiency & $\%$ & 38.3 & 22.0 & +16 & 174 \\
\hline Mineral fertilizer use & $\mathrm{kg} \mathrm{N} \mathrm{ha}^{-1}$ & 87 & 139 & -52 & 63 \\
\hline Concentrate use & $\mathrm{kg} \mathrm{N} \mathrm{ha}^{-1}$ & 78 & 96 & -18 & 81 \\
\hline Share of heifers & $\%$ & 31 & 34 & -3 & 91 \\
\hline Yearly income & $€$ per labour unit & 31059 & 27478 & +3581 & 113 \\
\hline
\end{tabular}

whole group of farms in 2000-2001, the top performing farms do not show major differences with regard to structural aspects such as farm area, stocking density or milk production per cow or per ha. This indicates a difference in operational management of $\mathrm{N}$, expressed in considerably lower use of fertilizer and concentrate $\mathrm{N}$ and, to a lesser extent, in a lower share of heifers in the herd. The actual management 
measures they take could not be derived from the FADN data. Potential aspects of operational management that are effective for attaining increased $\mathrm{N}$ use efficiency might be found in farm-specific measures such as crop rotation and ley/arable rotations (Nevens, 2003), increased forage milk production through ration optimization (Stuiver et al., 2003), incorporation of clover based swards (Cuttle and Turner, 2003), improved manure management (Jarvis and Menzi, 2004) and manure quality (Van Bruchem et al., 1999).

\subsection{Establishing reference values}

\subsubsection{Necessary threshold}

For a science-based determination of a farm-gate $\mathrm{N}$ surplus threshold that is necessary to comply with the European Nitrates Directive, there is a lack of scientific data in Flanders. Dutch results suggest that a soil $\mathrm{N}$ surplus of less than 110 $\mathrm{kg} \mathrm{N} \mathrm{ha}^{-1}$ year $^{-1}$ offers sufficient guarantee for groundwater nitrate contents below $50 \mathrm{mg}^{-1}$ (Ten Berge and Oenema, 2003). Given the similarity between Flemish and Dutch dairy farms and as on Flemish dairy farms the soil $\mathrm{N}$ balance surplus is consistently ca $40 \mathrm{~kg} \mathrm{~N}^{-1}$ less than the farm-gate $\mathrm{N}$ balance surplus (Verbruggen et al., 2004), whole-farm $\mathrm{N}$ surpluses of ca $150 \mathrm{~kg} \mathrm{ha}^{-1}$ year $^{-1}$ or lower would result in Nitrate Directive-compliant nitrate contents of groundwater $\left(<50 \mathrm{mg}\right.$ nitrate $\left.1^{-1}\right)$. The aim of the European Nitrate Directive is to reduce and prevent water pollution caused or induced by nitrates from agricultural sources.

\subsubsection{Feasible threshold}

With regard to technical feasibility, Fig. 2 illustrates that a farm-gate $\mathrm{N}$ surplus of about $150 \mathrm{~kg} \mathrm{ha}^{-1}$ year $^{-1}$ can be attained, also at production levels of up to 10,000 $1 \mathrm{ha}^{-1}$ (Flemish commercial farms) or even 12,000 $1 \mathrm{ha}^{-1}$ (experimental farm 'De Marke'). Also from an economic point of view we have strong indications that $150 \mathrm{~kg} \mathrm{~N} \mathrm{ha}^{-1}$ is a feasible threshold: at an average of $163 \mathrm{~kg} \mathrm{~N} \mathrm{ha}^{-1}$ year $^{-1}$ the selected group of progressive dairy farms is very close to the target and at the same time, their average income per unit of labour is $13 \%$ higher than the average of the total group of dairy farms (Table 4). Moreover, the average income of 31.1 kEuro labour unit ${ }^{-1}$ year $^{-1}$ reached by these progressive farms in 2000-2001 closely approaches the Belgian 'comparable income' (income realized for comparable labour in other economic sectors) which was $34.3 \mathrm{kEuro}$ in 2000-2001 (CLE, 2002). Such a comparable income level is often set as the target for labour income from sustainable agricultural activity.

\subsubsection{Optimal threshold}

A third level for a reference value could be based on optimization. Once dairy farms can operate within the necessary and feasible boundaries of farm-gate $\mathrm{N}$ surpluses, the most sustainable systems are those working at the highest level of ecoefficiency. For dairy farming, eco-efficiency (with regard to $\mathrm{N}$ ) can be defined as the amount of milk produced (as measure of production) per $\mathrm{kg}$ of $\mathrm{N}$ surplus (as measure of potential environmental damage). Fig. 3 shows that during 1989-1990, 90\% 


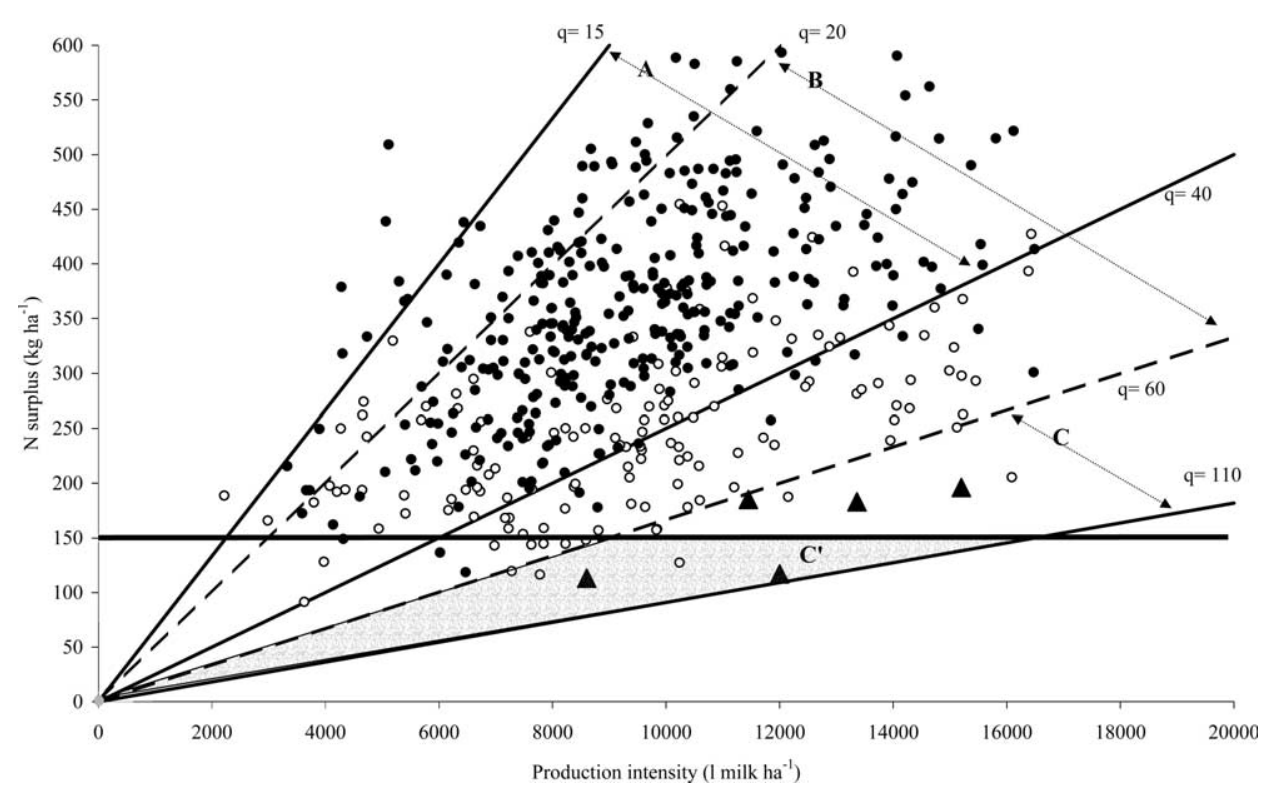

Fig. 3. Farm-gate N surpluses in relation to production intensity: Flemish dairy farms in 1989-1990 (O) and in 2000-2001 (O). Dutch experimental farms or farm groups ( $\mathbf{\Delta})$. Isoquants of eco-efficiency $(q, 1 \mathrm{milk}$ $\mathrm{kg}^{-1} \mathrm{~N}$ surplus). More details in text.

of the FADN dairy farms operated between eco-efficiency isoquants of 15 and 40 (zone A). The data cloud moved in time and during 2000-2001, 90\% of the same sample farms produced 20-60 1 milk kg-1 $\mathrm{N}$ surplus (Fig. 3, zone B). By that time, the selected top performing dairy farms produced $40-801$ milk per $\mathrm{kg} \mathrm{N}$ surplus. In the zone of maximum eco-efficiency, defined on the basis of the Dutch experimental farms or farm groups (delimited by the isoquants of 60 and 1101 milk kg $\mathrm{kg}^{-1}$ of N surplus; Fig. 3, zone C) the average value is 85 . Only $4 \%$ of the Flemish dairy farms investigated operated in this target zone during 2000-2001.

\subsubsection{Integrated target zone}

Taking into account the three selected reference value requisites, we can delimit an optimal operational zone for sustainable milk production (Fig. 3, zone $\mathrm{C}^{\prime}$ ). When available land is scarce (as is the case in Flanders), the most optimum part of this zone is the upper right (where 'De Marke' operates). Currently, the optimum zone is sparsely populated but the presence of some farms shows that actual practice dairy farming management within this zone is possible. Finally, the position of the optimum zone, as well as the data from 1989 to 1990 and 2000 to 2001 in Fig. 3 illustrate that the most 'sustainable' (in terms of eco-efficiency defined here) farms are not necessarily the most extensive ones. Also intensive systems (up to 12,000 $1 \mathrm{ha}^{-1}$ ) should be able to reach a farm-gate $\mathrm{N}$ surplus of about $150 \mathrm{~kg} \mathrm{~N} \mathrm{ha}^{-1}$ year $^{-1}$, and at the same time work with an acceptable eco-efficiency and use less space than required by more extensive systems to sustain comparable levels of production. 


\section{Conclusions}

During the past 15 years, Flemish dairy farms have considerably improved their $\mathrm{N}$ use efficiency: from 1989 to 2001 average annual farm-gate $\mathrm{N}$ surplus decreased from 378 to $238 \mathrm{~kg} \mathrm{ha}^{-1}$; the corresponding whole-farm $\mathrm{N}$ efficiency increased from $15 \%$ to $22 \%$.

The most progressive Flemish dairy farms show that there is significant scope for improved $\mathrm{N}$ use efficiency that is at the same time profitable from an economic point of view. Major progress in eco-efficiency should not be realized by radical structural changes but by tailor-made aspects of the operational management, resulting in significant reductions in fertilizer- and concentrate- $\mathrm{N}$ use. Although still far away for the majority of farms, reasonable targets for sustainable dairy farming in Flanders are $150 \mathrm{~kg} \mathrm{~N} \mathrm{ha}^{-1}$ year $^{-1}$ for the farm-gate $\mathrm{N}$ surplus and about $85 \mathrm{~kg}$ milk kg ${ }^{-1} \mathrm{~N}$ surplus for eco-efficiency. These targets can be reached at production levels of up to 10.000 à 12.0001 ha $^{-1}$ and at a satisfactory income per unit of labour.

\section{Acknowledgements}

The authors gratefully thank the Centre for Agricultural Economics (D. Van Lierde, L. Lauwers and V. Campens) for kindly putting the FADN data at their disposal.

\section{References}

Anonymous, 2000. MINAS Tabellenbrochure 2001. (MINAS brochure of tables). Accessed on: $<$ http:// www.minlnv.nl/minas/bib/brochure>.

Anonymus, 2003. Resultaten proefbedrijf 'De Marke'. Accessed on: <www.koeienenkansen.nl>.

CLE, 2002. Evolutie van de land- en tuinbouweconomie in 2001 (evolution of the agricultural and horticultural economy during 2001). In: Proceedings of the 40th Annual Report of the Centre for Agricultural Economics, Brussels, $132 \mathrm{p}$ (in Dutch).

Cuttle, S.P., Turner, M.M., 2003. Effectiveness of alternative managements to reduce N losses from dairy farms. In: Hatch, D.J., Chadwick, D.R., Jarvis, R.C., Roker, J.A. (Eds.), Controlling Nitrogen Flows and Losses. Wageningen Academic Publishers, Wageningen, pp. 498-499.

CVB (Centraal Veevoederbureau), 2002. Tabellenboek Veevoeding 2002. Book of Tables for Livestock Feeding 2002. CVB, Lelystad, the Netherlands, CVB-series no. 27, 118 p.

De Clercq, P., Gertsis, A.C., Hofman, G., Jarvis, S.C., Neeteson, J.J., Sinabell, F., 2001. Nutrient Management Legislation in European Countries (NUMALEC). Departement Soil Management and Soil Care, Ghent University, Belgium.

DeSimone, L.D., Popoff, F., 1997. Eco-efficiency. The Business Link to Sustainable Development. Massachusetts Institute of Technology Press, Cambridge, UK, p. 280.

De Vries, C., 2003. Duurzaam pionieren. Presentatie 'Koeien \& Kansen'-workshop: 'Stikstofhuishouding \& milieukwaliteit', 22 april, Wageningen, 4 p.

EU (European Union), 1991. Council directive 91/676/EEC of 12 December 1991 concerning the protection of waters against pollution caused by nitrates from agricultural sources. Official Journal of the European Communities, L375, 31/12/1991, 1-8. 
Goodlass, G., Halberg, N., Verschuur, G., 2003. Input output accounting systems in the European community - an appraisal of their usefulness in raising awareness of environmental problems. European Journal of Agronomy 20, 17-24.

Grignani, C., Sacco, D., Bassanino, M., Mantovi, P., Bonazzi, G., Cumino, P., 2003. Nutrient management on farm scale: attaining policy objectives in regions with intensive dairy farming: the Italian case. In: Bos, J., Pfimlin, A., Aarts, F., Vertès, F. (Eds.), Nutrient Management on Farm Scale, Workshop Proceedings, Quimper, France, pp. 120-135.

Hanegraaf, M., den Boer, D.J., 2003. Perspectives and limitations of the Dutch minerals accounting system (MINAS). European Journal of Agronomy 20, 25-31.

Humphreys, J., Casey, I.A., Carton, O.T., 2003. Meeting environmental objectives and potential constraint on dairy production in Ireland. In: Bos, J., Pfimlin, A., Aarts, F., Vertès, F. (Eds.), Nutrient Management on Farm Scale, Workshop Proceedings, Quimper, France, pp. 161-184.

Jarvis, S.C., 1999. Accounting for nutrients in grassland: challenges and needs. In: Corall, A.J. (Ed.), Accounting for Nutrients: A Challenge for Grassland Farmers in the 21st Century, Britisch Grassland Society Occasional Symposium No. 33, BGS Conference, Great Malvern, UK, 22-23 November 1999, Britisch Grassland Society, Reading, UK, pp. 3-12.

Jarvis, S.C., Aarts, H.F.M., 2000. Nutrient management from a farming systems perspective. In: Søegaard, K., Ohlsson, C., Sehested, J., Hutchings, N.J., Kristensen, T. (Eds.), Grassland Farming. Balancing Environmental and Economic Demands. Proceedings of the 18th General Meeting of the European Grassland Federation, Aalborg, Denmark, pp. 363-373.

Jarvis, S., Menzi, H., 2004. Optimising best practice for N management in livestock systems: meeting production and environmental targets. In: Lüscher, A., Jeangros, B., Kessler, W., Huguenin, O., Lobsiger, M., Millar, N. and Suter, D. (Eds.), Land Use Systems in Grassland Dominated Regions. Proceedings of the 20th General Meeting of the European Grassland Federation, Luzern, Switzerland, pp. 361-372.

Kristensen, E.S., Hogh Jensen, H., Kristensen, I.S., 1995. A simple model for estimation of atmospherically derived nitrogen in grass-clover systems. Biological Agriculture and Horticulture 12, 263-276.

Kristensen, I.B., Halberg, N., Højlund, A., Dalgaard, R., Hutchings, N., 2003. Agricultural nutrient management in Denmark. Part 2. N turnover on Danish mixed dairy farms. In: Bos, J., Pfimlin, A., Aarts, F., Vertès, F. (Eds.), Nutrient Management on Farm Scale, Workshop Proceedings, Quimper, France, pp. 85-98.

Lantinga, E., Groot, J., 1996. Optimization of grassland production and herbage feed quality in an ecological context. In: Utilization of Local Feed Resources by Dairy Cattle. EAAP Publication No. 84. Wageningen Academic Publishers, Wageningen, the Netherlands, pp. 58-66.

Le Gall, A., 2000. Bilans des minéraux dans les exploitations laitières bretonnes. Excédents et facteurs de variation. Institut de l'Elevage de Bretagne, France, Compte rendu d'action no 2003318, 32 p.

Le Gall, A., 2003. Impact des réglementations environnementales sur les systèmes laitiers. Institut de l'Elevage de Bretagne, France, Compte rendu d'action no 2033307.

Michiels, J., Verbruggen, I., Carlier, L., 1998. Mineralenbalansen en hun gebruik op melkveebedrijven. In: Van Huylenbroeck, G., Jacobs, G. (Eds.), Naar Een Duurzame Grasland - En Groenvoederuitbating. Belgian Ministry of Agriculture, Brussels, Belgium, pp. 27-49.

Mounsey, J., Sheehy, J., Carton, O.T., O’Toole, P., 1998. Nutrient management planning on Irish dairy farms. End of project report, Johnstown Castle Research Centre, Wexford, Ireland, $22 \mathrm{p}$.

Mulier, A., Hofman, G., Baecke, E., Carlier, L., De Brabander, D., De Groote, G., De Wilde, R., Fiems, L., Janssens, G., Van Cleemput, O., Van Herck, A., Van Huylenbroeck, G., Verbruggen, I., 2001. Emissiepreventie in de landbouw door middel van nutriëntenbalansen, Gent, 239 p.

Nevens, F., 2003. Nitrogen use efficiency in grassland, silage maize and ley/arable rotations. Ph.D. thesis. Gent University, Belgium, 231 p.

Öborn, I., Edwards, A.C., Witter, E., Oenema, O., Ivarsson, K., Withers, P.J.A., Nilsson, S.I., Richert Stinszing, A., 2003. Element balances as a tool for sustainable nutrient management: a critical appraisal of their merits and limitations within an agronomic and environmental context. European Journal of Agronomy 20, 211-225. 
Oenema, J., 2003. Stikstofhuishouding in 'Koeien \& Kansen'. Presentatie 'Koeien \& Kansen'-workshop: 'Stikstofhuishouding \& milieukwaliteit', 22 april, Wageningen, $10 \mathrm{p}$.

Oenema, O., Kros, H., de Vries, W., 2003. Approaches and uncertainties in nutrient budgets: implications for nutrient management and environmental policies. European Journal of Agronomy 20, 3-16.

Oenema, O., Pietrzak, S., 2002. Nutrient management in food production: achieving agronomic and environmental targets. Ambio 31, 159-168.

Ondersteijn, C.J.M., 2002. Nutrient management strategies on Dutch dairy farms: an empirical analysis. Ph.D. thesis. Wageningen University, Wageningen, $200 \mathrm{p}$.

Ondersteijn, C.J.M., Beldman, A.C.G., Daatselaar, C.H.G., Giesen, G.W.J., Huirne, R.B.M., 2002. The Dutch Mineral Accounting System and the European Nitrate Directive: implications for N and $\mathrm{P}$ management and farm performance. Agriculture, Ecosystems and Environment 92, 283296.

Overvest, J., 2002. Voorstelling resultaten AP Minderhoudhoeve, PMOV-studiedag, 20 juni, Swifterbant, the Netherlands.

Pfimlin, A., Aarts, H.F.M., Vertès, F., Bos, J.F.P.P., 2004. Diversity in European dairy farming systems and its environmental consequences. In: Lüscher, A., Jeangros, B., Kessler, W., Huguenin, O., Lobsiger, M., Millar, N., Suter, D. (Eds.), Land Use Systems in Grassland Dominated Regions. Proceedings of the 20th General Meeting of the European Grassland Federation, Luzern, Switzerland, pp. 816-818.

Pietrzak, S., Oenema, O., 2003. Nitrogen balances of dairy farms in Poland following drastic changes in agriculture. Abstracts for the 12th N Workshop, 21-24 September 2003, Exeter, IGER, UK, 2 p.

Schröder, J.J., Aarts, H.F.M., ten Berge, H.F.M., van Keulen, H., Neeteson, J.J., 2003. An evaluation of whole-farm nitrogen balances and related indices for efficient nitrogen use. European Journal of Agronomy 20, 33-44.

Schröder, J.J., Scholefield, D., Cabral, F., Hofman, G., 2004. The effects of nutrient losses from agriculture on ground and surface water quality: the position of science in developing indicators for regulation. European Journal of Agronomy 7, 15-23.

Seiler-Hausmann, J.-D., Liedtke, C., von Weizsäcker, E., 2004. Eco-efficiency and Beyond. Towards the Sustainable Enterprise. Greenleaf Publishing, Sheffield, UK, p. 248.

Sheringer, J., 2002. Nitrogen on Dairy Farms: Balances and Efficiency. Göttinger Agrarwissenschaftliche Beiträge; Band 10. University of Göttingen, Göttingen, p. 110.

Sleutel, S., De Neve, S., Hofman, G., Boeckx, P., Beheydt, D., Van Cleemput, O., Mestdagh, I., Lootens, P., Carlier, L., Van Camp, N., Verbeeck, H., Vande Walle, I., Samson, R., Lust, L., Lemeur, R., 2003. Carbon stock changes and carbon sequestration potential in Flemish cropland soils. Global Change Biology 9, 1193-2003.

Snijders, P., Everts, H., 2000. Mineralenbalans, stikstofbinding en waterkwaliteit. Biologische veehouderij en management (Bioveem). Publicatie 144, Praktijkonderzoek Rundvee, Schapen en Paarden, Lelystad, the Netherlands, pp. 61-64.

Stuiver, M., Van der Ploeg, J.D., Leeuwis, C., 2003. The VEL and VANLA environmental co-operatives as field laboratories. Netherlands Journal of Agricultural Science 51, 27-39.

Swensson, C., 2002. Ammonia release and nitrogen balances on south Swedish dairy farms 1997-1999. Doctoral thesis. Swedish University of Agricultural Sciences, Uppsala, Sweden, 67 p.

Swensson, C., 2003. Analysis of mineral element balances between 1997 and 1999 from dairy farms in the south of Sweden. European Journal of Agronomy 20, 63-69.

Soler-Rovira, J., Soler-Rovira, P., Soler-Soler, J., 2001. Environmental pressures and national environmental legislation with respect to nutrient management: Spanish case. In: De Clercq, P., Gertsis, A.C., Hofman, G., Jarvis, S.C., Neeteson, J.J., Sinabell, F. (Eds.), Nutrient Management Legislation in European Countries. Departement Soil Management and Soil Care, Ghent University, Belgium, pp. $114-137$.

Taube, F., Gierus, M., Kelm, M., 2003. Nutrient management on farm scale: attaining policy objectives in regions with intensive dairy farming: the German case. In: Bos, J., Pfimlin, A., Aarts, F., Vertès, F. (Eds.), Nutrient Management on Farm Scale, Workshop Proceedings, Quimper, France, pp. 35-61. 
Ten Berge, H., Oenema, J., 2003. Indicatoren voor waterkwaliteit in de melkveehouderij. De resultaten uit Koeien \& Kansen 1999-2002 op een rij. Presentatie in 'Koeien \& Kansen'-workshop: 'Stikstofhuishouding \& milieukwaliteit', 22 april 2003, Wageningen, Nederland, 17 p.

Van Bruchem, J., Verhoeven, F.P.M., Brussaard, L., Tamminga S., 1999. Diet and manure characteristics in relation to nitrogen flows in a dairy farming system. In: Regulation of Feed Intake. Proceedings of the 5th Zodiac Symposium, CAB International, Wallingford, pp. 219-227.

Van der Hem, A., 2003. De cijfers achter Vel \& Vanla. Natuurlijk in balans 4, 7-9.

Van der Hoek, K., 1990. Mineralenboekhouding melkveehouderij. CLM-, DLV- IKC-veehouderijuitgave, Utrecht, $37 \mathrm{p}$.

Van Gijseghem, D., Overloop, S., 2002. MIRA (2002) Milieu- en natuurrapport Vlaanderen, Achtergronddocument 2002, 2.12 Vermesting. Vlaamse Milieumaatschappij, 75 p. Accessed at: <http:// www.milieurapport.be>.

Van Rompaey, A., Govers, G., Waumans, T., Van Oost, K., Poesen, J., Desmet, J., 1999. A regional soil erosion map for Flanders @Wel 3, 1-6.

Verbruggen, I., 2001. Milieutechnische en voedingstechnische aspecten. In: Carlier, L. (Ed.), Duurzame Melkveehouderij Meetjesland. DFE-Merelbeke, p. 47.

Verbruggen, I., Michiels, J., Carlier, L., Van Bockstaele, E., 1996. Verslagen over De Voornaamste Resultaten Bekomen in De Periode 1994-1996 Van Het Nationaal Centrum Voor Grasland- En Groenvoederonderzoek, $1^{\mathrm{e}}$ Sectie. Centre for Agricultural Research, Gent, Belgium, 53 p.

Verbruggen, I., Nevens, F., Reheul, D., Hofman, G., 2004. Nitrogen Use and Efficiency in Flemish Dairy Farming. Flemish Policy Research Centre for Sustainable Agriculture, Publication 6, Gontrode, Belgium, $58 \mathrm{p}$ (in Dutch).

Vertès, F., Alard, V., Le Corre, L., 2002. Les exploitations étudiées. Résultats environnementaux. In: Alard, V., Béranger, C., Journet, M. (Eds.), A La Recherche D'une Agriculture Durable. Etude De Systèmes Herbagers économes En Bretagne. INRA Editions, Paris, pp. 115-144.

Whitehead, D.C., 1995. Grassland Nitrogen. CAB International, Wallingford, UK, 397 p. 